\title{
SUMMARY
}

Bondarenko Konstantin, Bondarenko Alla, Nikitina Anastasia. Change of splits jump technique in the process of training sessions.

Increasing the role of individual control over the performance of movements and ensuring correction of training activities on the basis of individual perception of skeletal muscles loads of different directions is an important task. Qualified gymnasts took part in the study. The purpose of the study was to determine the effectiveness of training special gymnastic exercises based on biomechanical analysis of movement. To solve this goal, we used the method of paired landmarks of movement and the method of myometry. The initial, final, starting and a number of animated positions were identified, which allowed not only to identify the criteria for rationality of movement, but also typical errors that occur as a result of fatigue.

A structural-phase model of performing a splits jump was built on the basis of different movement landmarks. Evaluation of changes in the performance of skeletal muscles was determined by serial performance of the exercise in one training session. Testing was performed after each serial repetition. M uscle tone at rest, skeletal muscle elasticity, level of strength potential and efficiency of tower work were evaluated.

The main parameters of changes in the functional state of skeletal muscles are revealed. The quantitative parameters of the seriality of a special exercise are determined. Parameters of the functional state of skeletal muscles allowed us to evaluate the contribution of skeletal muscles to ensure the effectiveness of gymnastic exercises.

The study revealed the appearance of typical errors when performing the exercise against the background of fatigue, namely: insufficient amplitude of movement at the moment of repulsion; the lack of synchronicity of the fixed position of the hands at the time of straightening the legs in the twine; at the moment of the unsupported phase, the torso is tilted forward, which reduces the height of the jump and can lead to a fall and injury; flexion of the legs at the knee joints at the moment of the twine position; landing on straight legs; relaxed landing and unnecessary movements, which make the body position limited-stable.

In the future, it is expected to identify the biomechanical relationship of gymnastic exercises on kinematic and dynamic parameters of movement and quantitative parameters to ensure the effectiveness of motor activity.

Keyword: boundary positions, skeletal muscles, functional state, physical exercises.

удк $372.3+376+616.7$

Павло Бочков

Національний педагогічний

університет імені М. П. Драгоманова

ORCID ID 0000-0001-5228-8630

DOI 10.24139/2312-5993/2020.02/336-348

\section{ВИКОРИСТАННЯ ТРЕНАЖЕРІВ У ФОРМУВАННІ ПОСТУРАЛЬНИХ МЕХАНІЗМІВ ПРИ ПОРУШЕННЯХ РІВНОВАГИ У ДОШКІЛЬНИКІВ}

у статті досліджено можливості використання матеріально-технічних засобів у подоланні порушень рівноваги в дошкільників. Зроблено огляд досліджень із чієї проблеми, виявлено проблематику, яка ще недостатньо досліджена. Особлива увага приділялася розробці та використанню авторських тренажерів для фрізичного виховання дітей дошкільного віку з синдромом постурального дефіциту. Було розглянуто й охарактеризовано такі тренажерні конструкції, як «Неспокійна піраміда», «Дирижабль», «Канатна дорога». По кожному тренажеру було надано його технічну характеристику, поради щодо їх виготовлення та експлуатації, а 
також розкрито його методичні можливості щодо подолання порушень рівноваги в дошкільників у вигляді конкретних комплексів корекційних вправ.

Ключові слова: тренажери, порушення функції рівноваги, дошкільники, постуральна система апломбу.

Постановка проблеми. Розвиток функції рівноваги в дітей дошкільного віку з порушеннями опорно-рухового апарату має відбуватися в системному форматі, коли будуть поєднуватися можливості спеціальних корекційних вправ, спрямованих на стимулювання всіх інформаційних каналів системи рівноваги, із можливостями матеріально-технічного забезпечення корекційного процесу відповідним предметно-просторовим оточенням. Перш за все, маються на увазі спеціальні тренажерні конструкції, за допомогою яких можна стимулювати, розвивати та коригувати функцію рівноваги в дітей із порушеннями ОРА.

Аналіз актуальних досліджень. Огляд літератури з проблеми показав, що дослідженнями можливостей використання тренажерів для формування в дітей дошкільного віку функції рівноваги в різні часи займалися фахівці з корекційного виховання та рухової реабілітації. Так, М. М. Єфименко та М. Д. Мога $(1987,1991,2009,2013,2014)$ досліджували особливості застосування авторських тренажерів у корекційно спрямованому фізичному вихованні дітей дошкільного віку, які страждають на церебральний параліч, а також таких, що мають парези церебрального та спінального рівня. В.І. Козявкін із колегами (2013) вивчали можливості застосування в лікувальній фізичній культурі дітей із ДцП танцювального килимка для формування функції рівноваги на місці. О. А. Холодов (2005) досліджував функцію рівноваги як складову в навчанні дітей із церебральним паралічем самостійному ходінню. Ю. А. Гросс та М. А. Гросс (1998, 2000) експериментували з підвісним «тренажером Гросса» для формування в дітей з ДЦП можливості зберігати рівновагу в ортоградному двохопірному положенні, а також під час самостійної ходьби.

Віддаючи належне виконаним фахівцями дослідженням, слід зауважити, по-перше, що всі вони, головним чином, були присвячені категорії дітей, які страждають на ДЦП, що не є завданням наших пошуків. По-друге, колеги не використовували у своїх дослідженнях сучасні комп'ютерні здобутки у вигляді стабілографії з ії можливостями об'єктивно та комплексно аналізувати стан змін цієї функції після формувального педагогічного експерименту.

Наведене вище дозволяє вважати тему використання авторських тренажерів у покращенні функції рівноваги в дошкільників із моторними порушеннями вельми актуальною.

Мета статті полягає у вивченні можливостей застосування авторських тренажерів «Неспокійна піраміда», «Дирижабль» та «Канатна дорога» для розвитку та корекції функції рівноваги в зазначеного контингенту дітей. 
Методи дослідження. Для досягнення поставленої мети використовувалися такі методи: метод аналізу й систематизації інфрормації щодо вітчизняного та зарубіжного досвіду 3 проблем використання спеціальних тренажерів для розвитку функції рівноваги в дітей - використовувався для дослідження ступеня наукових розробок та визначення можливості практичного використання різних тренажерних конструкцій у корекційному фізичному вихованні дітей дошкільного віку 3 синдромом постурального дефіциту; обстеження фізичного розвитку дітей (спостереження, порівняння) - для виявлення особливостей та ефективності розвитку функції рівноваги в зазначеного контингенту дітей на запропонованих авторських тренажерах.

Виклад основного матеріалу. Зупинимося докладніше на тренажері «Неспокійна піраміда» (фото 1).

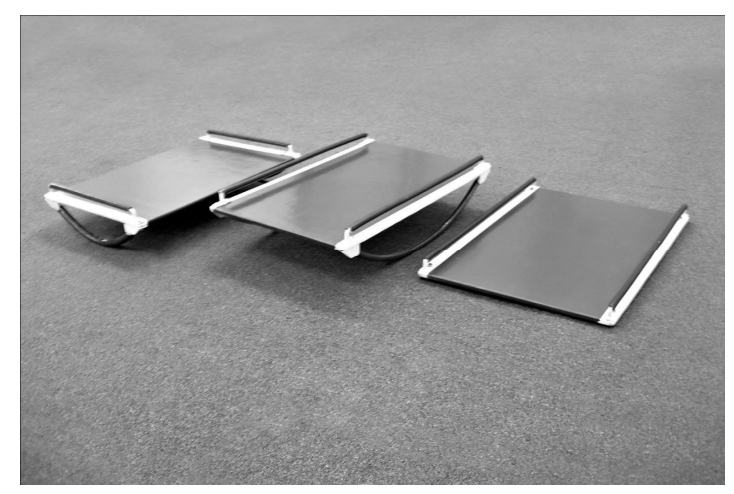

Фото 1

Цей тренажер, як і наступні два, були створені в Центрі реабілітації рухом (ЦРР) дітей з порушеннями ОРА, який було засновано в 1990 році М. М. Єфименком. Він і $€$ автором ідеї тренажера та його попереднього експериментального зразка. Далі цю загальну ідею дозованого одночасного коливання в усіх площинах на вищому технологічному рівні оформив та постійно доопрацьовував у своїх експериментальних дослідженнях співробітник Центру М.Д. Мога (Ефименко та Мога, 2011; Мога, 2007; Мога, 2003; Мога, 2000).

Основу тренажера становить фанера товщиною 12 мм, металевий обертовий диск «Здоров'я» (або аналогічний йому), сферичні полози 3 металевого прута, ручки-фіксатори та пінополіуретанові килимки (рис. 1).

Збираються тренажерні підконструкції таким чином:

- «Дошка-оберталочка» - диск «Здоров'я» прикручується до фанерної основи на перетині двох його діагоналей зі зворотного боку, а рейки-фіксатори кріпляться по краях довгої сторони.

- «Човник» - з металевого прута вигинається відповідна дуга, на яку надівається захисний шланг такого самого розміру, після чого полози кріпляться вздовж до фанерної опори зі зворотного боку, а ручкифіксатори зверху, також уздовж країв довгих сторін. 
- «Качалочка» - верхня й найменша складова тренажерного комплексу: збирається так само, як і «Човник», тільки полози кріпляться не вздовж, а поперек основи.

«Неспокійна піраміда» покривається лаком або ж фарбою відповідних кольорів, які підходять інтер'єру фізкультурної зали. Зверху на кожен із трьох тренажерів можна класти амортизаційні або масажні килимки.
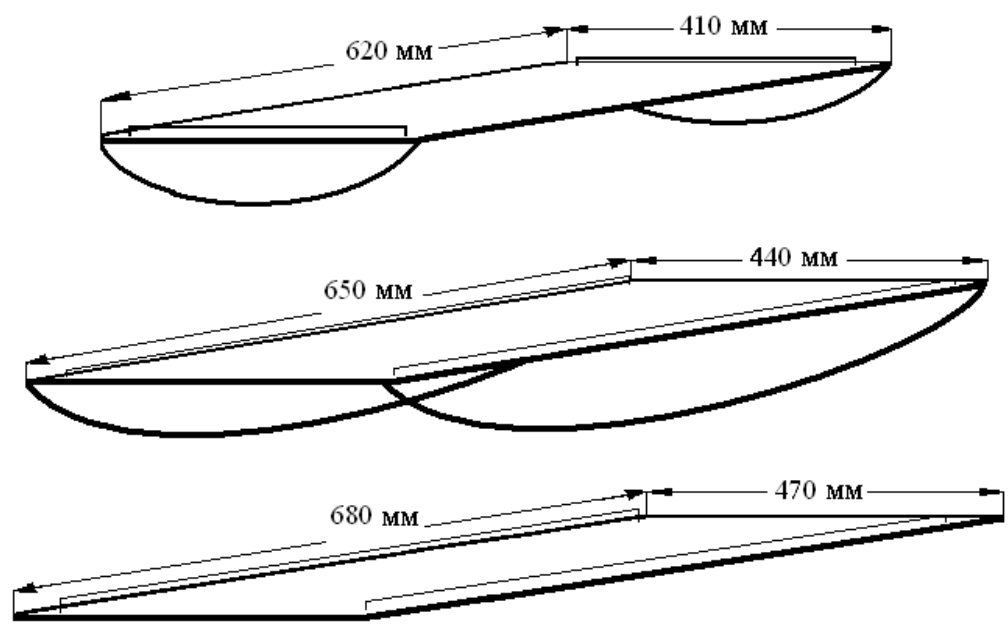

Рис. 1

Практика багаторічної фізичної реабілітації дітей дошкільного віку 3 порушеннями ОРА показала значні методичні можливості цієї тренажерної конструкції. На тренажері «Неспокійна піраміда» можна стимулювати майже всі канали постуральної системи апломбу (вестибулярний, зоровий, окуломоторний, проприоцептивний та подарний). Нижче буде наведено орієнтовний комплекс вправ із розвитку та корекції функції рівноваги у зазначеного контингенту дітей:

1. 3 вихідного положення (в.п.) стоячи на «Дошці-оберталочці» зберігати стійкість під час обертання конструкції педагогом (спочатку дуже повільно, потім повільно і дали з поступовим збільшенням швидкості обертання).

2. 3 в.п. стоячи на «Човнику» зберігати стійкість під час дозованих розгойдувань конструкції педагогом вліво - вправо 3 поступовим збільшенням амплітуди коливання.

3. 3 в.п. стоячи на «Гойдалці» зберігати стійкість під час дозованих розгойдувань конструкції педагогом вперед - назад із поступовим збільшенням амплітуди коливання.

4. 3 в.п. стоячи на «Дошці-оберталочці» зберігати стійкість під час самостійного обертання на тренажері (спочатку дуже повільно, потім повільно і дали з поступовим збільшенням швидкості обертання).

5. 3 в.п. стоячи на «Човнику» зберігати стійкість під час самостійних розгойдувань конструкції дитиною вліво - вправо 3 поступовим збільшенням амплітуди коливання. 
6. 3 в.п. стоячи на «Гойдалці» зберігати стійкість під час самостійних розгойдувань конструкції дитиною вперед - назад із поступовим збільшенням амплітуди коливання.

7. 3 в.п. стоячи на «Човнику» та «Дошці-оберталочці» (перший тренажер стоїть на другому) зберігати стійкість під час обертань і розгойдувань тренажерів педагогом, які треба робити з поступовим збільшенням швидкості обертання та амплітуди розгойдування.

8. 3 в.п. стоячи на «Човнику» та «Дошці-оберталочці» (перший тренажер стоїть на другому) зберігати стійкість під час самостійних обертань і розгойдувань дитиною з поступовим збільшенням швидкості обертання та амплітуди розгойдування.

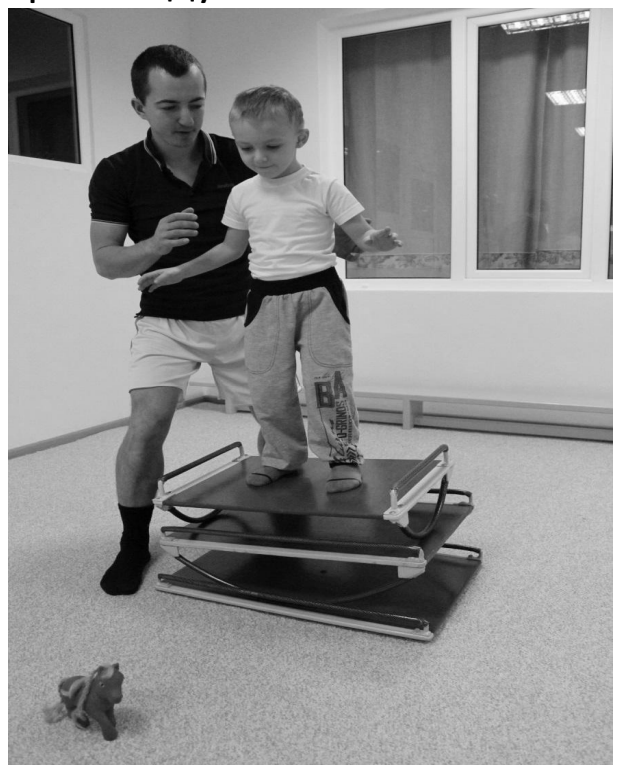

Фото 2

9. 3 в.п. стоячи на «Неспокійній піраміді» (на всіх трьох складових тренажера) зберігати стійкість під час обертань і розгойдувань тренажерів педагогом у всіх площинах, які треба робити з поступовим збільшенням швидкості обертання та амплітуди розгойдування.

10. 3 в.п. стоячи на «Неспокійній піраміді» (на всіх трьох складових тренажера) зберігати стійкість під час самостійних обертань і розгойдувань тренажерів дитиною в усіх площинах, які треба робити з поступовим збільшенням швидкості обертання та амплітуди розгойдування (фото 2).

Надалі ці вправи можна поступово ускладнювати шляхом таких методичних прийомів:

А) додаючи дозовані балістичні рухи рукою або руками за типом фехтування гімнастичною палицею з умовними негативними казковими персонажами;

Б) танцюючи на тренажері під музичний супровід;

В) виконуючи кидки м'яча та його ловіння;

Г) зменшуючи зоровий контроль за оточуючим простором (періодично заплющуючи очі). 
Перейдемо до опису тренажера «Дирижабль». Він складається із пластмасової бочки об'ємом близько 40-50 літрів, трьох пластикових поручнів, дитячого гімнастичного (металевого) обруча, двох петельфіксаторів для зап'ястя, одного обважнювача-стабілізатора (до 10 кг) і диска, що обертається (типу «Здоров'я») (рис. 2).

Таким чином, стропи, на яких підвішується даний тренажер, розраховані на навантаження, що в кілька разів перевищує вагу дитини та тренажера. Сама конструкція бочки також $\epsilon$ гарантом безпеки навіть для дитини, яка ще не дуже впевнено стоїть. Глибина і діаметр бочки такі, що не дозволяють підопічному швидко і кардинально втратити рівновагу і, тим більше, випасти з неї.

Під час занять фізичною культурою особливу увагу слід приділяти самій рухово-ігровій діяльності - при цьому повинна бути гарантована стовідсоткова безпека малюка за будь-яких варіантів його поведінки на тренажерній конструкції. Так, на тренажері «Дирижабль» під час широко амплітудного розгойдування зростає небезпека перекидання бочки разом із дитиною назад. Ця проблема була вирішена такими технічними засобами:

- на дно бочки був прикріплений обважнювач-стабілізатор у вигляді металевого млинця від штанги вагою 5-10 кг. Таким чином, центр мас всієї системи концентрується внизу, що значною мірою ускладнює перекидання основного елемента конструкції (тобто бочки);

- перекидання також можна уникнути, якщо застосувати різні петліфіксатори для ручного та кистьового захвату. Цьому сприятимуть і самі стропи, розташовані вертикально й паралельно (двохопорний вертикальний захват), що дозволяє стабілізувати дитину у відносно стійкому положенні;

- з цією ж метою були розроблені зручні для кистьового захвату вертикальні пластмасові поручні, нанизані на стропи, а також горизонтально розташований вгорі металевий обруч. Він сприяє максимально можливому випрямленню тулуба та кінцівок у позі прямостояння, покращує опорні реакції таза й ніг, формує відчуття ортоградного положення.

Особливо актуальна підвищена страховка при горизонтальному використанні «Дирижабля», коли чотири основні точки кріплення розташовуються ближче до країв конструкції та фіксуються карабінами (фото 3).

Для ускладнення горизонтального використання даної конструкції зменшується кількість точок кріплення - до двох посередині, що дозволяє виконувати маятникоподібні рухи вперед і назад, обертання на 360 легкі бічні похитування. У даному випадку дитині стає складніше утримувати рівновагу, тому концентрація уваги педагога повинна бути максимальною, адже застосування обважнювача-стабілізатора тут не передбачається. 
Puc. 2
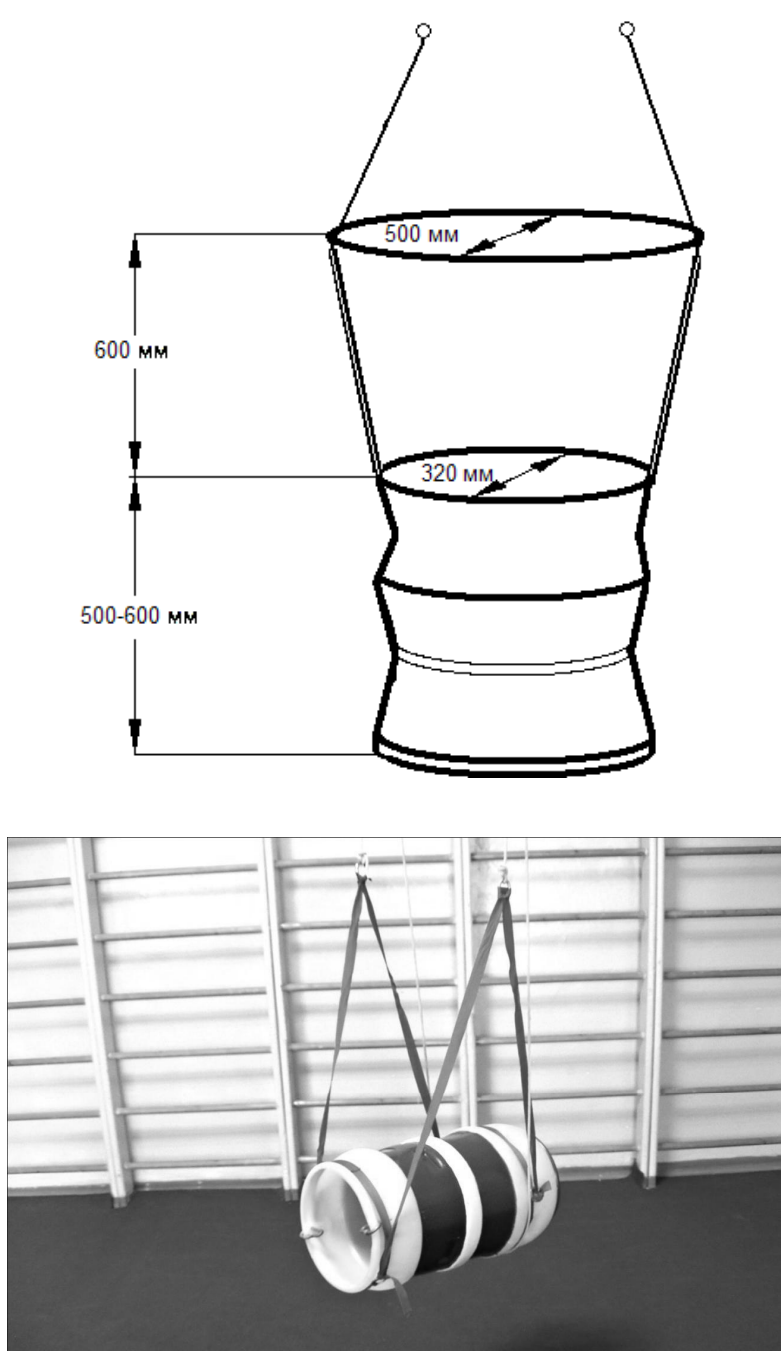

Фото 3

Нижче, як приклад, пропонуємо орієнтовний комплекс вправ на тренажері «Дирижабль»:

1. 3 в.п. стоячи в бочці тренажера розгойдуватися вперед - назад за допомогою педагога, поступово збільшуючи амплітуду коливань.

2. 3 в.п. стоячи в бочці тренажера розгойдуватися вліво - вправо за допомогою педагога, поступово збільшуючи амплітуду коливань.

3. 3 в.п. стоячи в бочці тренажера розгойдуватися вперед - назад та вліво - вправо за допомогою педагога, поступово збільшуючи амплітуду коливань.

4. 3 в.п. стоячи в бочці тренажера розгойдуватися за допомогою педагога вперед - назад, вліво - вправо, напівприсідаючи та встаючи при цьому, поступово збільшуючи амплітуду коливань.

5. 3 в.п. стоячи в бочці тренажера розгойдуватися за допомогою педагога вперед - назад, вліво - вправо, змінюючи положення рук на стропах із високого до низького, поступово збільшуючи амплітуду коливань (фото 4).

6. 3 в.п. стоячи в бочці тренажера розгойдуватися за допомогою педагога вперед - назад, вліво - вправо, тримаючись за стропи почергово то лівою, то правою рукою, поступово збільшуючи амплітуду коливань. 
7. 3 в.п. стоячи в бочці тренажера розгойдуватися за допомогою педагога вперед - назад, вліво - вправо, самостійно розвертаючись при цьому приставними кроками на 180ㅇ, поступово збільшуючи амплітуду коливань.

8. 3 в.п. стоячи в бочці тренажера розгойдуватися за допомогою педагога вперед - назад, вліво - вправо, самостійно розвертаючись при цьому приставними кроками на 360ㅇ, поступово збільшуючи амплітуду коливань.

9. 3 в.п. стоячи в бочці тренажера на обертальному диску розгойдуватися за допомогою педагога вперед - назад, вліво - вправо, самостійно розвертаючись при цьому за допомогою балістичних рухів на 180 으, поступово збільшуючи амплітуду коливань.

10. 3 в.п. стоячи в бочці тренажера на обертальному диску розгойдуватися за допомогою педагога вперед - назад, вліво - вправо, самостійно розвертаючись при цьому за допомогою балістичних рухів на 360ํ, поступово збільшуючи амплітуду коливань.

Фото 4

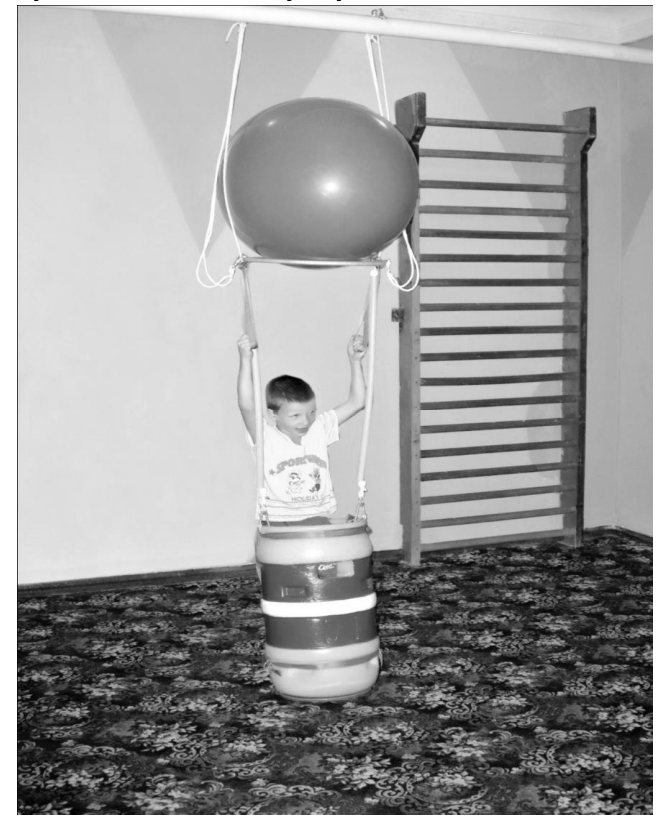

Надалі ці вправи можна ускладнювати за допомогою таких методичних прийомів:

А) самостійного розгойдування тренажера вперед - назад і вліво вправо;

Б) за умови утримування однією рукою при цьому іграшки;

В) підстрибуючи на тренажері;

г) зменшуючи зоровий контроль за оточуючим простором завдяки світлозахисній пов'язці на очах.

Третій тренажер цієї серії - «Канатна дорога» (фото 5). Він призначений головним чином для використання в умовах фізкультурних залів дошкільних і шкільних установ, центрів реабілітації, санаторіїв. Але якщо у вашій квартирі 
або будинку $\epsilon$ відносно простора кімната - «Канатна дорога» може вдало вписатися в ії інтер'єр, оскільки за обсягом займає мінімум місця. Даний тренажер чудово доповнить і будь-яку ландшафтну зону - його можна легко натягнути та закріпити між двома міцними деревами або стовпами. щоправда, у цьому випадку особливу увагу потрібно буде приділити страховці дітей (забезпеченню системи їхньої безпеки).

Тренажер дуже простий і складається 3 товстого (діаметром у 15-20 мм) синтетичного троса й одного-двох стандартних вертлюгів, за допомогою яких конструкція натягується між двома опорами. Можна використовувати також замуровані в стіну гаки (скоби) (рис. 3). У більшості випадків тренажер «Канатна дорога» розташовується між двома паралельно встановленими гімнастичними драбинами на відстані 4-8 м; мінімальна поперечна відстань до стіни складає 40-50 см. Натяг тренажера регулюється за допомогою вертлюгів, які з міркувань безпеки та естетики зачохлені дерматиновими кожухами типу нарукавників з поролоновим прошарком всередині. «Канатна дорога» може встановлюватися на будьяку необхідну висоту, під різним нахилом; відстань між верхньою (ручною) і нижньою (ножною) струнами також може регулюватися.

Між цими струнами закріплюються різні зйомні штучні перешкоди, від найлегшої (у вигляді вертикальної жердини) до складніших і цікавіших варіантів (типу «рамки», «обруча» та ін.). Перешкод можна встановити відразу декілька (3-5), замінюючи їх у процесі проведення одного або декількох занять. Пропонований тренажер краще розташовувати вздовж однієї зі сторін по периметру зали, біля стіни або закріплених гімнастичних драбин.

\section{Фото 5}
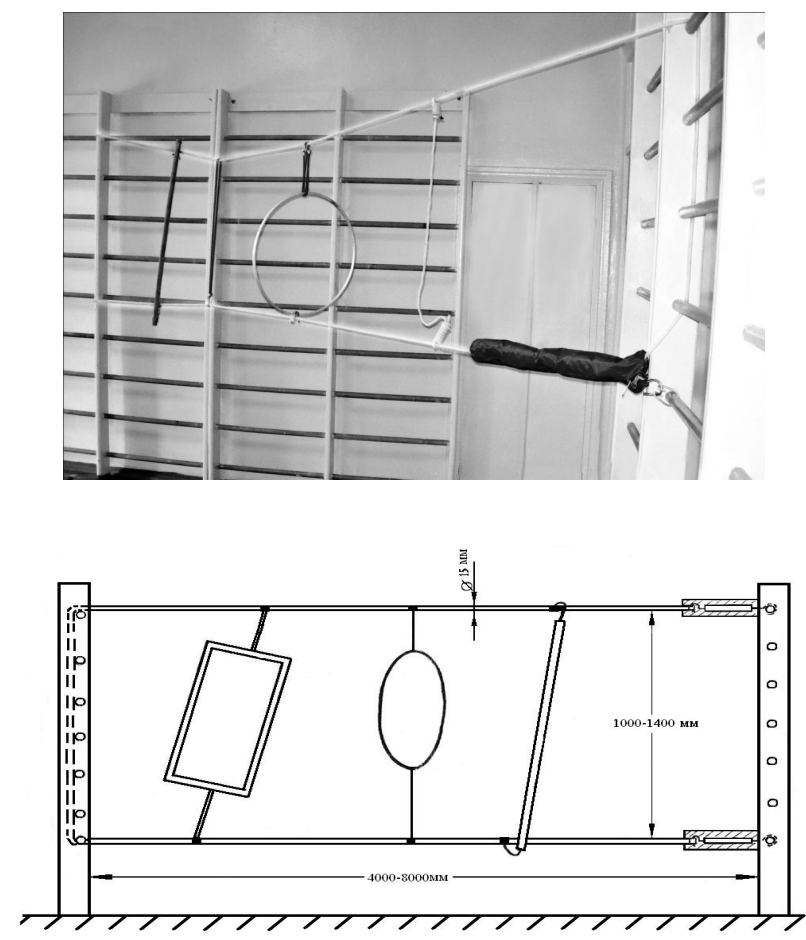

Рис. 3 
Тренажер «Канатна дорога» дозволяє виконати на ньому такі орієнтовні вправи для покрашення функції рівноваги:

1. 3 в.п. стоячи на тренажері зберігати стійке положення тіла у просторі.

2.3 в.п. стоячи на тренажері зберігати стійке положення тіла у просторі, розгойдуючись при цьому вверх - вниз і поступово збільшуючи амплітуду коливань.

3.3 в.п. стоячи на тренажері зберігати стійке положення тіла у просторі, розгойдуючись при цьому в усіх площинах (вверх - вниз, вліво вправо, вперед - назад) і поступово збільшуючи амплітуду коливань.

4. Повільна ходьба по тренажеру боком приставними кроками на невеликій висоті (нижній канат має бути на рівні 0,5-1 м від підлоги) з підтримкою з боку педагога 3 поступовим збільшенням швидкості пересування.

5. Повільна ходьба по тренажеру боком приставними кроками на середній висоті (нижній канат має бути на рівні 1-1,25 м від підлоги) 3 підтримкою 3 боку педагога 3 поступовим збільшенням швидкості пересування.

6. Повільна ходьба по тренажеру боком приставними кроками на відносно великій висоті (нижній канат має бути на рівні 1,25-1,75 м від підлоги) з підтримкою з боку педагога 3 поступовим збільшенням швидкості пересування.

7. Самостійна ходьба по тренажеру боком приставними кроками на невеликій висоті (нижній канат має бути на рівні 0,5-1 м від підлоги) 3 поступовим збільшенням швидкості пересування.

\section{Фото 5}

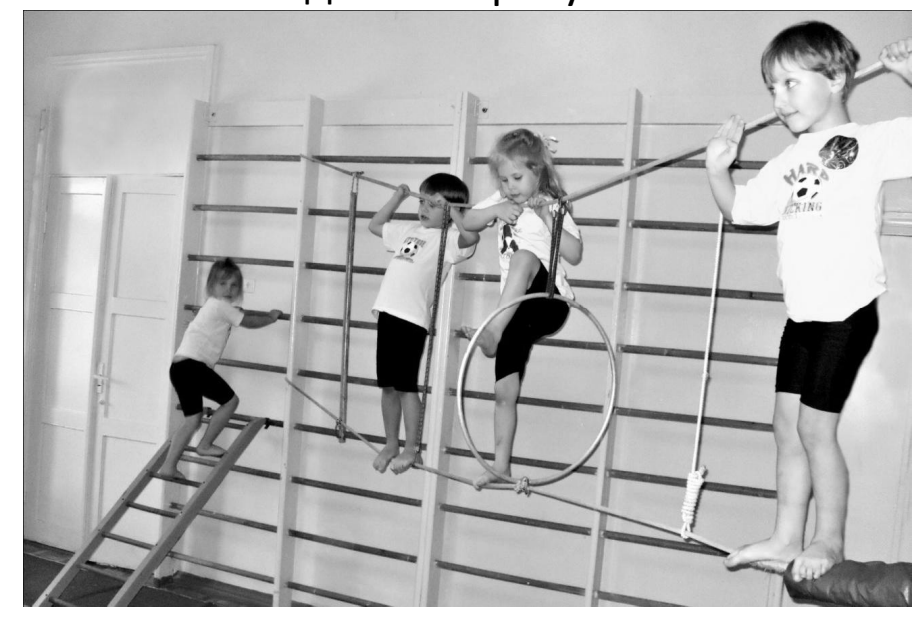

8. Самостійна ходьба по тренажеру боком приставними кроками на середній висоті (нижній канат має бути на рівні 1-1,25 м від підлоги) 3 поступовим збільшенням швидкості пересування.

9. Самостійна ходьба по тренажеру боком приставними кроками на відносно великій висоті (нижній канат має бути на рівні 1,25-1,75 м від підлоги) з поступовим збільшенням швидкості пересування. 
10. Самостійна ходьба по тренажеру боком приставними кроками на середній та великій висоті 3 поступовим збільшенням швидкості пересування, педагог при цьому виконує похитування тренажера в різних площинах (фронтальний, сагітальній та горизонтальній).

Надалі ці вправи можна ускладнювати, використовуючи таки додаткові методичні прийоми:

А) виконуючи звичайну ходьбу обличчям уперед;

Б) виконуючи нетипову ходьбу спиною вперед;

В) обертаючись під час ходьби почергово в різні боки на 360;

г) долаючи під час ходьби різні штучні горизонтальні та/або вертикальні перешкоди (фото 5).

Підбиваючи підсумки виконаного дослідження, необхідно зробити попередні висновки:

1. Використання технічних засобів у вигляді авторських тренажерів значно мотивує дітей на виконання необхідних вправ і прискорює розвиток та корекцію функції рівноваги.

2. Підвищення ефективності покращення функції рівноваги в дошкільників із порушеннями ОРА треба шукати в напрямі поєднання можливостей вправляння на опорі 3 використанням спеціальних авторських тренажерів.

Перспективи подальшого дослідження проблеми використання тренажерів у формуванні постуральних механізмів у дітей лежать у площині розробки нових тренажерних конструкцій та поповнення арсеналу корекційних вправ на тренажерах «Неспокійна піраміда», «Дирижабль»та «Канатна дорога».

Перспективи подальших наукових досліджень у цьому напрямі простежуються в розробці нових тренажерних конструкцій для розвитку функції рівноваги в дітей дошкільного віку з синдромом постурального дефіциту, а також у комбінуванні методичних прийомів стимулювання всіх п'яти каналів постуральної системи апломбу в різних комбінаціях у пошуках найбільш ефективних варіантів.

\section{ЛІТЕРАТУРА}

Гросс, Н.А. (2000). Физическая реабилитация детей с нарушениями функций опорнодвигательного аппарата. М.: Советский спорт (Gross, N. (2000). Physical rehabilitation of children with musculoskeletal system disorders. M oscow: Soviet Sport).

Гросс, Ю.А. (1998). Применение тренажерных устройств в реабилитационных занятиях физическими упражнениями детей с нарушениями опорнодвигательного аппарата (автореф. дис. ... канд. педагогических наук). М. (Gross, Yu. (1998). The use of simulators in rehabilitation of children with musculoskeletal system disorders with the help of physical exercises (PhD thesis abstract). M oscow).

Ефименко, Н.Н. (1986). Особенности двигательных нарушений дошкольников с церебральным параличом и пути их коррекции средствами физического воспитания (дис. ... канд. пед. наук: 13.00.03). Одесса (Efimenko, N. (1986). 
Features of motor disorders of preschoolers with cerebral palsy and ways of their correction by means of physical education (PhD thesis). Odessa).

Єфименко, М. М. (2013). Сучасні підходи до корекційно спрямованого фрізичного виховання дошкільників з порушеннями опорно-рухового апарату. Вінниця: Нілан-лтД (Efimenko, N. (2013). Modern approaches to correctionally directed physical education of preschool children with musculoskeletal system disorders. Vinnytsia: Nilan-LTD).

Ефименко, Н. Н., Мога, Н. Д. (2011). Авторские тренажеры в физическом воспитании и двигательной реабилитации детей. Винница: Глобус Пресс (Efimenko N., Moga N. (2011). Author's simulators in physical education and motor rehabilitation of children: a training manual. Vinnytsia: Globus Press).

Козявкін, В.І., Качмар, О.О., Аблікова, І. В., Качмар Б. О. (2013). Реабілітаційна комп'ютерна ігротерапія із використанням танцювального килимка. Соціальна педіатрія та реабілітологія, 2, 20-25 (Koziavkin, V., Kachmar, O., Ablikova, I., Kachmar, B. (2013). Rehabilitation computer game therapy using a dance rug. Social pediatrics and rehabilitation, 2 (1), 20-25).

Мога,Н.Д. (2007). Коррекция двигательных нарушений у детей дошкольного возраста с детским церебральным параличом (дис. ... канд. педаг. наук: 13.00.03). Одесса (Moga, N. (2007). Correction of motor disorders of preschool children with cerebral palsy. (PhD thesis). Odessa).

Мога, Н. Д., Ефименко, Н. Н. (2003). Тренажеры-игрушки (материально-техническое обеспечение физического воспитания и оздоровления детей). Наша школа, 3, 35-39 (Moga, N., Efimenko, N. (2003). Simulators-toys (material and technical support of physical education and health of children). Our school, 3 (1), 35-39).

Мога, Н. Д., Ефименко, Н.Н. (2000). Создай тренажеры сам (материальнотехническое обеспечение физического воспитания и оздоровления детей). Hаша школа, 2/3, 229-232 (Moga, N., Efimenko, N. (2000). Create simulators yourself (material and technical support of physical education and health of children). Our school, 2 (3), 229-232).

Холодов, С. А. (2005). Формирование навыков ходьбы у детей дошкольного возраста со спастическими формами детского церебрального паралича (дис. ... канд. педаг. наук: 13.00.03). Одесса (Kholodov, S. (2005). Walking skills development of preschool children with spastic forms of cerebral palsy. (PhD thesis). Odessa).

\section{PEЗЮME}

Бочков Павел. Использование тренажеров в формировании постуральных механизмов при нарушении равновесия у дошкольников.

В статье исследованы возможности использования материальнотехнических средств в преодолении нарушений равновесия у детей. Особое внимание уделялось разработке и использованию авторских тренажеров для физического воспитания детей дошкольного возраста с синдромом постурального дефицита. Были рассмотрены и охарактеризованы такие тренажерные конструкции, как «Беспокойная пирамида», «Дирижабль», «Канатная дорога». По каждому тренажеру была представлена его техническая характеристика, советы по изготовлению и эксплуатации, а также его методические возможности по преодолению нарушений равновесия у детей в виде конкретных комплексов коррекционных упражнений.

Ключевые слова: тренажеры, нарушение функции равновесия, дошкольники, постуральная система апломба. 


\section{SUMMARY}

Bochkov Pavio. The use of simulators to form postural mechanisms during equilibrium disbalance of preschoolers.

The article explores the possibilities of using material and technical means for overcoming children's imbalances. Literature review on this problem is made, the problems are identified, which have not yet been sufficiently studied.

Particular attention was paid to development and use of authoring simulators for physical education of junior age children with postural deficiency syndrome.

Such simulator constructions as "Restless Pyramid", "Airship", "Cable Car" were considered and characterized. For each simulator were provided its technical characteristics, advice on their manufacture and operation.

Separately for each simulator, its methodological capabilities for overcoming children imbalance in the form of specific complexes of corrective exercises are given.

Each simulator was analyzed from the perspective of its use in five directions, corresponding to the presence of inputs (channels) in the child according to the general postural system of maintaining equilibrium (vestibular, visual, oculomotor, proprioceptive and gift).

M ethodological tips are given for ensuring both the general safety system of children during exercise in physical education classes and specific recommendations for the safe operation of each simulator.

It is proved that simulators are most effective of their together usage with the surrounding 3D correction space. Particular attention was paid to the author's threecomponent and three-level simulator "Restless Pyramid", which allows the child to train the function of dynamic stability in all three planes: frontal, sagittal and horizontal.

With the help of these three simulators, it is possible to effectively form a child's static balance (in place), semi-dynamic balance (moving in place) and dynamic balance (in motion with movement).

Key words simulators, imbalance, junior age children, postural aplomb system.

удК 378.147:811.111

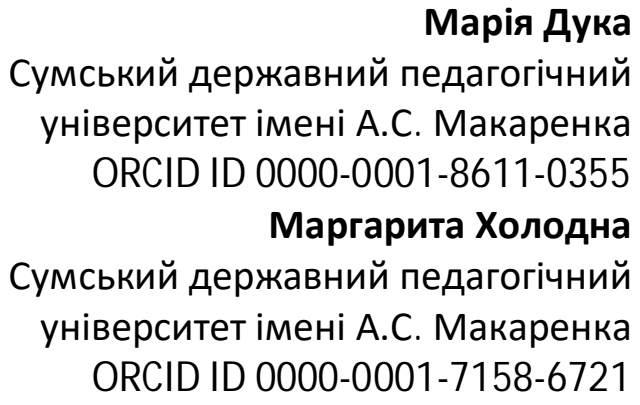

DOI 10.24139/2312-5993/2020.02/348-361

\section{ОСОБЛИВОСТІ ФОРМУВАННЯ АНГЛОМОВНОЇ СОЦІАЛЬНОЇ КОМПЕТЕНТНОСТІ У ПРОЦЕСІ НАВЧАННЯ ДІАЛОГІЧНОГО МОВЛЕННЯ В УЧНІВ 6-ГО КЛАСУ ЗАКЛАДІВ ЗАГАЛЬНОЇ СЕРЕДНЬОЇ ОСВІТИ}

у статті висвітлено низку теоретичних положень щодо особливостей формування англомовної соціальної компетентності у процесі навчання діалогічного мовлення учнів 6-го класу закладів загальної середньої освіти. Систематизовано підходи до визначення поняття «англомовна сочіальна компетентність» та проаналізовано ії специфрічні складники: знання правил вербального й невербального спілкування, мовного етикету, табу, ритуалів, звичаїв та вміння такими знаннями користуватися на практиці. Уточнено складники компетентності в діалогічному мовленні. Узагальнено 